\title{
Serviceability performance of steel-concrete composite beams
}

1 R. Mark Lawson $\mathrm{PhD}, \mathrm{BSc}($ Eng), CEng, MICE, MIStructE Professor, Steel Construction Institute, Ascot, UK; University of Surrey, Guildford, UK (corresponding author: m.lawson@steel-sci.com)

2 Dennis Lam BEng, MPhil, PhD, CEng, MICE, FIStructE, MASCE Chair of Structural Engineering, School of Engineering, University of Bradford, Bradford, UK
3 Eleftherios S. Aggelopoulos BEng, MSc, PhD, CEng, MICE Senior Engineer, Steel Construction Institute, Ascot, UK

4 Sebastian Nellinger Dr-Ing. Research Associate, University of Luxembourg, Kirchberg, Luxembourg
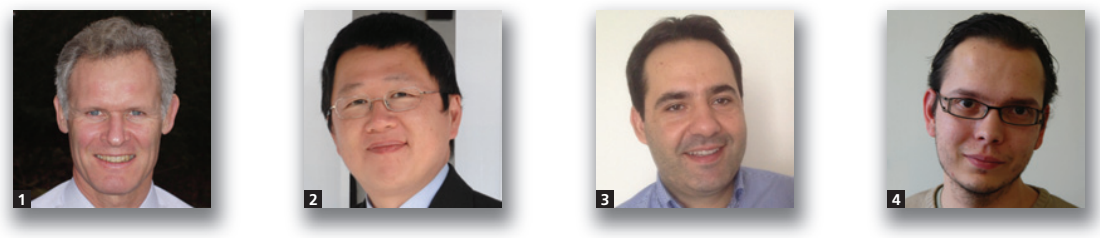

The use of steel-concrete composite beams in which wide-flanged steel beams act compositely with a concrete or steel-concrete composite slab above is well established in building construction. However, for composite beams with low degrees of shear connection between the beam and slab, significant additional deflections can occur due to slip in the shear connectors. A design formula is presented for the effective stiffness of composite beams taking account of the stiffness of the shear connectors, which is compared to measured deflections of six symmetric composite beams and an $11 \mathrm{~m}$ span composite beam of asymmetric profile. It is shown that the comparison is good when using a shear connector stiffness of $70 \mathrm{kN} / \mathrm{mm}$ for single shear connectors and $100 \mathrm{kN} / \mathrm{mm}$ for pairs of shear connectors per slab rib. The results of push tests on a range of slab profiles confirmed these initial elastic stiffnesses. To ensure that the slip at the serviceability limit state does not lead to permanent deformations of the composite beam, it is proposed that the minimum degree of shear connection should not fall below $30 \%$ for unpropped beams and $40 \%$ for propped beams of symmetric cross-section.

\section{Notation}

$A_{\mathrm{c}} \quad$ cross-sectional area of concrete slab within the effective width

$A_{\mathrm{fb}} \quad$ bottom flange area of steel section

$A_{\mathrm{ft}} \quad$ top flange area of steel section

$A_{\mathrm{s}} \quad$ cross-sectional area of steel section

$E_{\mathrm{c}} \quad$ elastic modulus of concrete slab

$E_{\mathrm{s}} \quad$ elastic modulus of steel section

F

$\bar{F}$

$h_{\mathrm{c}}$

$h_{\mathrm{p}}$

$I_{\mathrm{c}}$

$I_{\text {comp }}$

$I_{\text {eff }}$

$I_{\mathrm{s}}$

$I_{\mathrm{s}}$
$k$

k longitudinal compression force in concrete slab maximum force in concrete slab at mid-span depth of concrete over the concrete slab profile depth of concrete slab profile second moment of area of concrete slab second moment of area of composite beam for rigid shear connectors

second moment of area of composite beam taking account of slip

second moment of area of steel section

stiffness of shear connectors

composite beam span

externally applied moment

maximum moment at mid-span
$M_{\mathrm{c}} \quad$ moment resisted by concrete slab

$M_{\mathrm{pl}} \quad$ plastic bending resistance of composite beam

$M_{\mathrm{s}} \quad$ moment resisted by steel section

$M_{\mathrm{sw}} \quad$ moment due to self-weight loads applied to unpropped beam

$n \quad$ modular ratio of steel to concrete $=E_{\mathrm{s}} / E_{\mathrm{c}}$

$P \quad$ point load on composite beam in test

$P_{\mathrm{k}} \quad$ characteristic resistance of shear connector

$P_{\mathrm{Ed}, \mathrm{pl}} \quad$ point load on composite beam corresponding to its plastic bending resistance

$s \quad$ slip at any position, $x$, on the span

$\bar{s} \quad$ end slip at $x=0$ and $L$

$s_{\mathrm{sc}} \quad$ longitudinal spacing of shear connectors

$w_{\text {cdd }} \quad$ additional deflection due to end slip

$w_{\text {comp }} \quad$ deflection of composite beam based on inertia of $I_{\text {comp }}$

$w_{\mathrm{s}} \quad$ deflection of steel section for the same serviceability loading used to calculate $w_{\text {comp }}$

$\begin{array}{ll}x & \text { distance from support } \\ y_{\mathrm{s}} & \text { elastic neutral axis depth of steel section measured }\end{array}$

$y_{\mathrm{s}}$ from top of steel section

ultimate limit state 


\section{Introduction}

The use of steel-concrete composite beams in which wideflanged steel beams act compositely with a concrete or steelconcrete composite slab above is well established in building construction. They are especially used for office buildings and hospitals, where spans of 13-20 m are often required. Longspan composite beams are generally designed with a span/ depth ratio in the range of 24 to 28 and, for these slender beams, serviceability limits of deflection or vibration sensitivity are the controlling design criteria.

The design of composite beams is presented in BS EN 1994-1-1: Eurocode 4 (BSI, 2004) and the former BS 5950-3 (BSI, 1990) as well as in AISC 360-10 (AISC, 2010). The rules in these codes concentrate on the ultimate limit state (ULS) and on the methods of achieving longitudinal shear connection. Rules for design at the serviceability limit state (SLS) are more approximate, and the development of improved serviceability rules is the scope of this paper.

Modern composite construction usually involves the use of steel-concrete composite slabs. These typically span 3-4 m between the steel beams to form a grillage of secondary and primary beams, as shown in Figure 1. The steel decking used in a composite slab is typically $50-80 \mathrm{~mm}$ deep and the concrete slab is typically $130-160 \mathrm{~mm}$ deep.

At the ULS, the design of composite beams is normally based on plastic-analysis principles. Where the longitudinal force developed due to the combined resistance of the shear connectors is insufficient to develop the compression resistance of the slab or the tensile resistance of the steel beam, this is known as 'partial shear connection'. The degree of shear connection is defined as a percentage between $100 \%$ shear connection for the fully composite beam and zero for the steel beam.

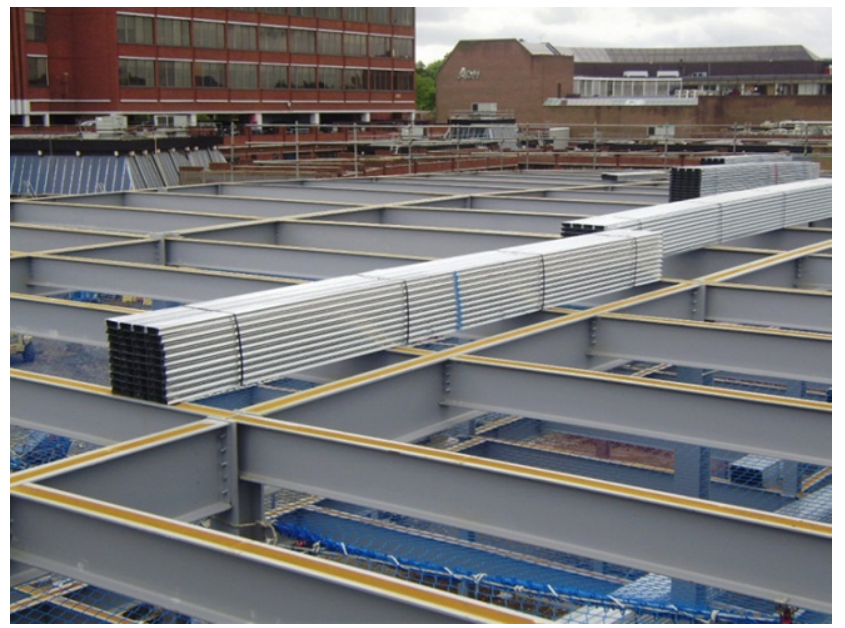

Figure 1. Composite beam grillage with profiled decking placed on the beams
Eurocode 4 (BSI, 2004) presents rules for the minimum degree of shear connection at the ULS that were developed for propped beams, where all loads are applied to the composite section. The shear connection rules were based on a limiting end slip of $6 \mathrm{~mm}$ at the plastic resistance of the beam. In clause 6.6.1.2 of Eurocode 4, the required minimum degree of shear connection increases linearly with beam span from a minimum of $40 \%$ up to $100 \%$ at $25 \mathrm{~m}$ span. In the NCCI (non-contradictory, complementary information) guidance (SCI, 2010) and the recent Steel Construction Institute (SCI) publication 405 (Couchman, 2015), which were produced to complement the use of Eurocode 4 for design in the UK, the minimum degree of shear connection is reduced for unpropped beams and for shear connectors with a higher limiting end slip of $10 \mathrm{~mm}$. This was based on evidence from push tests and finite-element (FE) modelling of composite beams.

However, a further unstated requirement of the minimum degree of shear connection is to ensure that elastic conditions hold at serviceability loads, in order to avoid irreversible deformations under repeated loading. This is expressed as a minimum cut-off in the degree of shear connection that is provided and, in Eurocode 4, the $40 \%$ cut-off was based on the analysis of propped beams. The work carried out leading to SCI P405 (Couchman, 2015) showed that this cut-off could be reduced for unpropped beams, but should be increased for asymmetric sections (with bottom flange larger than the top flange).

The slip that occurs between a beam and a slab is due to the flexibility of the shear connectors, which adds to deflections under working loads. The former BS 5950-3 (BSI, 1990) gave an approximate formula for the additional deflection as a function of the degree of shear connection, whereas, in Eurocode 4, it is not required to take account of additional deflections provided that the minimum degree of shear connection is satisfied and at least $50 \%$ shear connection is provided. No guidance is offered in Eurocode 4 as to how to calculate deflections for lower degrees of shear connection.

This paper addresses the effect of partial shear connection on deflections of composite beams and provides a formula for the effective stiffness of composite beams based on the stiffness of the shear connectors. It also defines the minimum degree of shear connection that is required to satisfy elastic conditions at the SLS. The method is calibrated against the results of both short- and long-span beam tests and FE models of composite beams in order to ensure its accuracy for design. This method is still work in progress because calibration against more beam tests is required, but it is shown here that the results match well the limited series of beam tests investigated.

\section{Existing formulae for deflection of composite beams}

The deflection of composite beams is calculated from the second moment of area (also known as the inertia) of the 
composite section, which is generally three to four times that of the steel beam. This elastic property is calculated for a particular ratio of the elastic moduli of the steel and concrete (modular ratio) on the assumption that the shear connectors are rigid for full shear connection. For a beam that is propped during construction, the long-term modular ratio should be used to calculate deflections on removal of the props.

Nethercot, Li and Ahmed (1998) considered the case when yielding of a composite beam may occur at the SLS for a range of deflection limits and showed the effect of partial yielding along the beam on deflections. This was based on high degrees of shear connection and allowed for connection fixity at the ends of the beam. However, in practice, long-span composite beams do not yield at serviceability loads and it is the slip in the shear connectors that adds to deflections.

For lower degrees of shear connection, a significant additional deflection occurs due to slip in the shear connectors at the SLS, and the slip increases as the degree of shear connection reduces. In order to develop simple rules for the effects of partial shear connection on deflections, it is assumed there is a correlation between the slip in the shear connectors at the SLS and the degree of shear connection at the ULS.

In BS 5950-3 (BSI, 1990), the additional deflection ( $w_{\text {add }}$ ) due to partial shear connection in unpropped beams is given by the relatively simple equation

1. $w_{\text {add }}=0 \cdot 3(1-\eta)\left(w_{\mathrm{s}}-w_{\text {comp }}\right)$
The coefficient of $0 \cdot 3$ applies to unpropped beams where the self-weight of the slab acts on the steel beam. This coefficient was established from comparisons with relatively short-span composite beam tests (Wright and Francis, 1990). For propped beams, the coefficient is taken as $0 \cdot 5$, as the load-slip behaviour of the shear connectors is non-linear and their stiffness reduces with the forces acting on them due to the additional self-weight loads applied on removal of the temporary props.

In AISC 360-10 (AISC, 2010), the additional deflection is presented in terms of a modified second moment of area of the composite section $\left(I_{\mathrm{c}, \mathrm{eff}}\right)$ given by

2. $\quad I_{\mathrm{c}, \mathrm{eff}}=I_{\mathrm{s}}+\eta^{0.5}\left(I_{\mathrm{comp}}-I_{\mathrm{s}}\right)$

Comparisons between the code methods are given later.

\section{Elastic design of composite beams}

Elastic design is used to check deflections and stresses of composite beams at the SLS, but may also be used at the ULS when the cross-section does not meet the class 1 or class 2 criteria in BS EN 1993-1-1: Eurocode 3 (BSI, 2005). Elastic design is also used for composite beams with non-ductile shear connectors that fail to meet the $6 \mathrm{~mm}$ limiting slip in Eurocode 4 (BSI, 2004).

Slip at the interface between the beam and slab leads to deformations along the beam, as shown in Figure 2. Furthermore, the lower the shear connector stiffness, the higher the

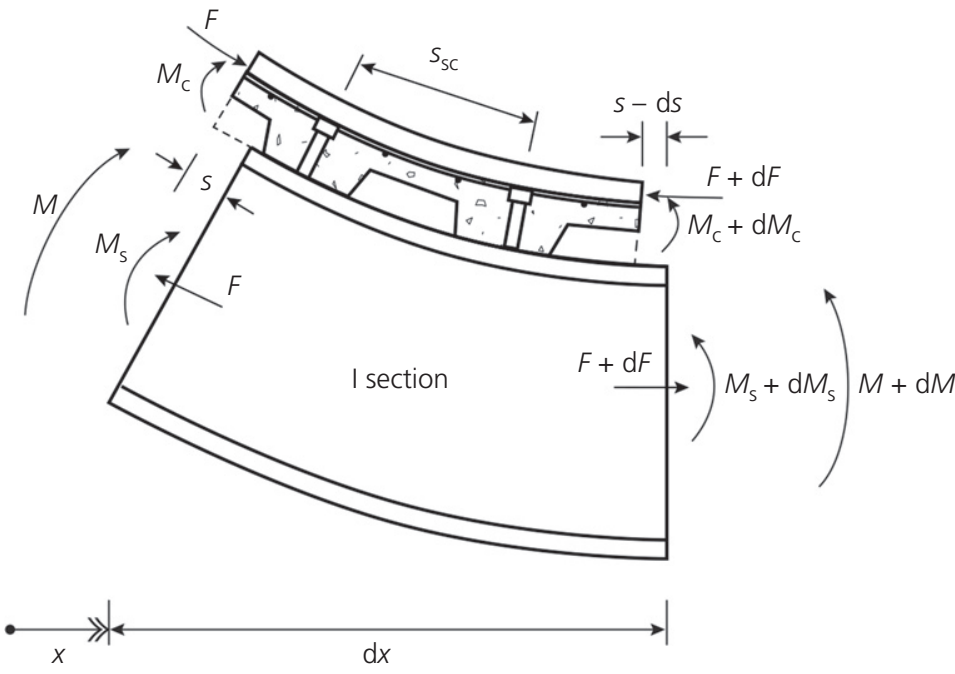

(a)

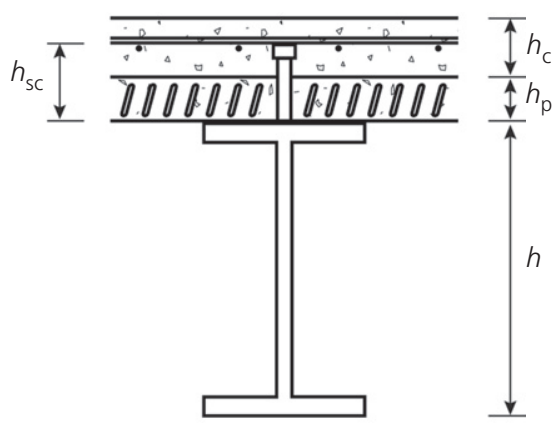

(b)

Figure 2. Forces and displacements in a composite beam as affected by slip: (a) side view of composite beam showing slip of shear connectors; (b) cross-section of composite beam 
deflection due to slip, but the lower the shear forces experienced in the outer shear connectors.

The first theory for the effects of partial shear connection on the design of composite beams was developed by Newmark et al. (1951), who presented a solution to a differential equation linking slip and deflection for beams with a single point load. The differential equation may also be solved for the general load case using the finite-difference method and many papers have covered this approach (e.g. Ranzi and Zona, 2007). Furthermore, the method may be adapted to consider combined shrinkage and slip effects in composite beams (Ranzi et al., 2003).

The following theory shows how the stiffness of shear connectors may be included in the calculation of the effective stiffness of composite beams and also in the longitudinal shear forces. It is based on the theory presented by Lam et al. (2000), which was developed for composite beams supporting precast concrete slabs. In this paper, the additional deflection due to the flexibility of the shear connectors is obtained for a uniformly loaded beam. The theory may be explained by making the assumption that the interface slip follows a simple function along the beam to a maximum slip at the ends of the span. The actual slip distribution along the beam will differ with the loading distribution, but comparison with full-scale beam tests shows that simplifications can be made for deflection calculations.

Other simplifying assumptions are that the elastic neutral axis lies in the steel section so that the concrete is uncracked and also that the effective width of the slab is the same as for the ULS (= beam span/4). Both of these assumptions are considered to be reasonable approximations for deflection calculations given that the beneficial effects of partial continuity at the connections are not included.

\subsection{Elastic stiffness of composite beams - rigid shear connectors}

For a composite beam connected to a composite slab, equilibrium of the forces and moments in the cross-section, as shown in Figure 2, is satisfied by

$$
\text { 3. } M=M_{\mathrm{c}}+M_{\mathrm{s}}+F\left(y_{\mathrm{s}}+h_{\mathrm{p}}+0 \cdot 5 h_{\mathrm{c}}\right)
$$

Assuming that there is no separation along the beam and no cracking of the slab, the curvature of the slab and the steel beam is the same at any position $x$, and the relative movement between the two determines the rate of change of slip according to

4. $\frac{\mathrm{d} s}{\mathrm{~d} x}=-\frac{M_{\mathrm{c}}}{E_{\mathrm{c}} I_{\mathrm{c}}}\left(h_{\mathrm{p}}+0 \cdot 5 h_{\mathrm{c}}\right)-\frac{M_{\mathrm{s}}}{E_{\mathrm{s}} I_{\mathrm{s}}}\left(y_{\mathrm{s}}\right)+\left(\frac{F}{E_{\mathrm{c}} A_{\mathrm{c}}}+\frac{F}{E_{\mathrm{s}} A_{\mathrm{s}}}\right)$ where

5. $\frac{M}{E_{\mathrm{s}} I_{\mathrm{eff}}}=\frac{M_{\mathrm{c}}}{E_{\mathrm{c}} I_{\mathrm{c}}}=\frac{M_{\mathrm{s}}}{E_{\mathrm{s}} I_{\mathrm{s}}}$

Solving these two equations gives

6. $M=-\frac{\mathrm{d} s}{\mathrm{~d} x} \frac{E_{\mathrm{s}} I_{\mathrm{eff}}}{y_{\mathrm{s}}+h_{\mathrm{p}}+0 \cdot 5 h_{\mathrm{c}}}+\frac{F I_{\mathrm{eff}}}{y_{\mathrm{s}}+h_{\mathrm{p}}+0 \cdot 5 h_{\mathrm{c}}}\left(\frac{A_{\mathrm{c}}+n A_{\mathrm{s}}}{A_{\mathrm{c}} A_{\mathrm{s}}}\right)$

For a fully composite beam with rigid shear connectors (with $s=0$ ), the second moment of area is given by

7. $I_{\text {comp }}=I_{\mathrm{s}}+I_{\mathrm{c}} / n+\left(y_{\mathrm{s}}+h_{\mathrm{p}}+0 \cdot 5 h_{\mathrm{c}}\right)^{2}\left(\frac{A_{\mathrm{c}} A_{\mathrm{s}}}{A_{\mathrm{c}}+n A_{\mathrm{s}}}\right)$

\subsection{Elastic stiffness of composite beams - flexible} shear connectors

The effective stiffness of a composite beam with flexible shear connectors is established from Equation 6. As a good approximation for a uniformly loaded beam, and to simplify the derivation of usable design formulae, the applied moment $(M)$ and compression force $(F)$ are taken as varying according to a sine function, and the slip $(s)$ as varying according to a cosine function with distance $x$ along the beam from a support. The true slip function is more complex, but this simple function is reasonably accurate for beams with uniform loading and is shown to be reasonably accurate for beams with point loads at the one-third span points.

The maximum compression force in the slab is determined from the integral of the forces in the shear connectors, which are a function of their elastic stiffness $(k)$, longitudinal spacing $\left(s_{\mathrm{sc}}\right)$ and end slip $(\bar{s})$ as follows

8. $\bar{F}=\int_{0}^{x} \frac{k}{s_{\mathrm{sc}}} \bar{s} \cos \left(\frac{\pi x}{L}\right)=\frac{L}{\pi} \frac{k}{s_{\mathrm{sc}}} \bar{s} \sin \frac{\pi x}{L}=\frac{L}{\pi} \frac{k}{s_{\mathrm{sc}}} \quad$ for $\quad x=L / 2$

and

9. $\frac{\mathrm{d} s}{\mathrm{~d} x}=\left(\frac{\pi}{L}\right) \bar{s} \sin \frac{\pi x}{L}$

Inserting the above equations into Equation 6 gives the following formula linking the end slip and mid-span moment, $\bar{M}$

$$
\text { 10. } \bar{s}=\frac{(L / \pi)\left(y_{\mathrm{s}}+0 \cdot 5 h_{\mathrm{c}}+h_{\mathrm{p}}\right) \bar{M}}{E I_{\mathrm{eff}}\left[1+(L / \pi)^{2} \cdot\left(\left(k / s_{\mathrm{sc}}\right) / E_{\mathrm{s}}\right) \cdot\left(\left(A_{\mathrm{c}}+n A_{\mathrm{s}}\right) / A_{\mathrm{s}} A_{\mathrm{c}}\right)\right]}
$$

The effective inertia of the composite beam as a function of the shear connector stiffness is

11. $I_{\mathrm{eff}}=I_{\mathrm{s}}+\frac{I_{\mathrm{c}}}{n}+\frac{\left(y_{\mathrm{s}}+0 \cdot 5 h_{\mathrm{c}}+h_{\mathrm{p}}\right)^{2}\left(A_{\mathrm{c}} / n\right)}{\left[1+A_{\mathrm{c}} /\left(n A_{\mathrm{s}}\right)+(\pi / L)^{2} \cdot\left(E_{\mathrm{s}} /\left(k / s_{\mathrm{sc}}\right)\right) \cdot\left(A_{\mathrm{c}} / n\right)\right]}$ 
The end slip in Equation 10 may be simplified as a function of the inertias of the composite section $\left(I_{\text {comp }}\right)$ for rigid shear connectors and of the steel section $\left(I_{\mathrm{s}}\right)$, making the assumption that the term $I_{\mathrm{c}} / n$ is small and can be neglected. It is given as follows for pairs of shear connectors per deck rib. In the Discco tests, an initial 25 cycles of load up to $40 \%$ of the predicted failure load were applied before testing to failure. The load-slip curves from representative tests are shown in Figures 4-8.

$$
\text { 12. } \quad \bar{s}=\frac{(L / \pi)\left(y_{\mathrm{s}}+0 \cdot 5 h_{\mathrm{c}}+h_{\mathrm{p}}\right) \bar{M}}{E I_{\mathrm{comp}}\left[\left(I_{\mathrm{s}} / I_{\mathrm{comp}}\right)+(L / \pi)^{2} \cdot\left(\left(k / s_{\mathrm{sc}}\right) / E_{\mathrm{s}}\right) \cdot\left(\left(A_{\mathrm{c}}+n A_{\mathrm{s}}\right) / A_{\mathrm{s}} A_{\mathrm{c}}\right)\right]}
$$

The maximum shear connector force is given by multiplying the end slip by the stiffness, $k$.

The additional mid-span deflection of the composite beam due to end slip relative to the deflection of the beam with rigid shear connectors is given by
For beams that are unpropped during construction, the relevant stiffness for serviceability calculations is taken as being the slope of the load-slip curve in the range of $0 \cdot 1 P_{\mathrm{k}}$ to $0 \cdot 4 P_{\mathrm{k}}$, which takes account of the loads acting on the shear connectors due to imposed loading as a proportion of the characteristic shear resistance of the shear connectors $\left(P_{\mathrm{k}}\right)$. For beams

13. $w_{\text {add }}=w_{\text {comp }}\left(\frac{1-\left(I_{\mathrm{s}} / I_{\text {comp }}\right)}{\left(I_{\mathrm{s}} / I_{\mathrm{comp}}\right)+(L / \pi)^{2}\left(\left(k / s_{\mathrm{sc}}\right) / E_{\mathrm{s}}\right) \cdot\left(\left(A_{\mathrm{c}}+n A_{\mathrm{s}}\right) / A_{\mathrm{s}} A_{\mathrm{c}}\right)}\right)$

It is not normally required to calculate the additional stresses due to partial shear connection but, in principle, the stresses in the flanges and concrete can be calculated knowing $I_{\text {eff }}$.

\section{Study on shear connector stiffness}

The elastic stiffness of single and pairs of shear connectors was obtained from the results of push-out tests carried out in a recent EU project called Discco (Development of improved shear connection rules in composite beams) and also from previous tests (Table 1). This review does not cover all existing push tests, which would have been a major investigation, but representative tests from the series were selected for this study. The main emphasis was on $19 \mathrm{~mm}$ diameter through-deck welded shear connectors placed in the middle of the deck ribs. The two trapezoidal deck profiles tested in the Discco project are shown in Figure 3 and covered a range of application. The nominal concrete grade was $30 / 37$ and measured cylinder strengths were approximately $40 \mathrm{~N} / \mathrm{mm}^{2}$.

The $80 \mathrm{~mm}$ deep deck profile had a wide rib and used $125 \mathrm{~mm}$ high shear connectors (120 mm as-welded height) in which the shear connectors were welded in the middle of the deck rib and were embedded only $40 \mathrm{~mm}$ into the concrete topping (Figure 3(b)). The $58 \mathrm{~mm}$ deep deck profile had a narrow rib and used $125 \mathrm{~mm}$ high shear connectors in which the shear connectors were embedded $62 \mathrm{~mm}$ into the slab (Figure 3(a)). Further tests were performed on $56 \mathrm{~mm}$ deep re-entrant decking, also using $125 \mathrm{~mm}$ high shear connectors.

These results were supplemented by additional tests on $60 \mathrm{~mm}$ and $80 \mathrm{~mm}$ deep deck profiles presented in SCI RT 1309 (SCI, 2009), which all used deliberately weaker concrete (C20 cylinder strength) so that the effect of the concrete grade on stiffness could be seen. In a push test, there are generally four shear connectors per specimen for single shear connector tests and eight with a higher span/depth ratio, this serviceability load will reduce, but $0.4 P_{\mathrm{k}}$ is a sensible upper bound for interpretation of push tests. The relevant stiffness for propped beams is taken as being the slope of the load-slip curve in the range $0 \cdot 1 P_{\mathrm{k}}$ to $0 \cdot 7 P_{\mathrm{k}}$ taking account of the loads acting on the shear connectors due to combined dead and imposed loading.

For pairs of shear connectors, the stiffness is presented per deck rib (i.e. for two shear connectors). Further tests were also carried out on the $58 \mathrm{~mm}$ deep deck profile orientated parallel to the beam with shear connectors placed at $200 \mathrm{~mm}$ spacing. It was expected that the shear stiffness for parallel decking would be higher than the equivalent transverse decking case.

In the early calibration studies for Eurocode 4, the mean stiffness of $19 \mathrm{~mm}$ diameter shear connectors in a solid slab using $\mathrm{C} 30 / 37$ concrete was taken as $100 \mathrm{kN} / \mathrm{mm}$ (Johnson and Molenstra, 1991). A load-slip function for the shear connectors is given (Aribert, 1997) as

14. $F_{\mathrm{s}}(s)=P_{\mathrm{k}}\left(1-\mathrm{e}^{-0.7 s}\right)^{0.8}$

Using this load-slip function, the equivalent stiffness for a shear connector in a solid slab at a slip of $0.2 \mathrm{~mm}$ (typical of a load of $0.4 P_{\mathrm{k}}$ ) is about $80 \mathrm{kN} / \mathrm{mm}$. For a slip of $0.4 \mathrm{~mm}$ (typical of a load of $0.7 P_{\mathrm{k}}$ ), the equivalent stiffness is about $70 \mathrm{kN} / \mathrm{mm}$, which is broadly consistent with the test values for profiled decking. Other authors (Qureshi et al., 2011a, 2011b) suggest that, for composite slabs, the shear stiffness can be approximated as $40-60 \%$ of the stiffness in a solid slab depending on the type and depth of decking and the position of the shear connector in the deck rib.

From these tests, representative stiffness values for decking orientated transverse to the beam axis are presented in Table 2 


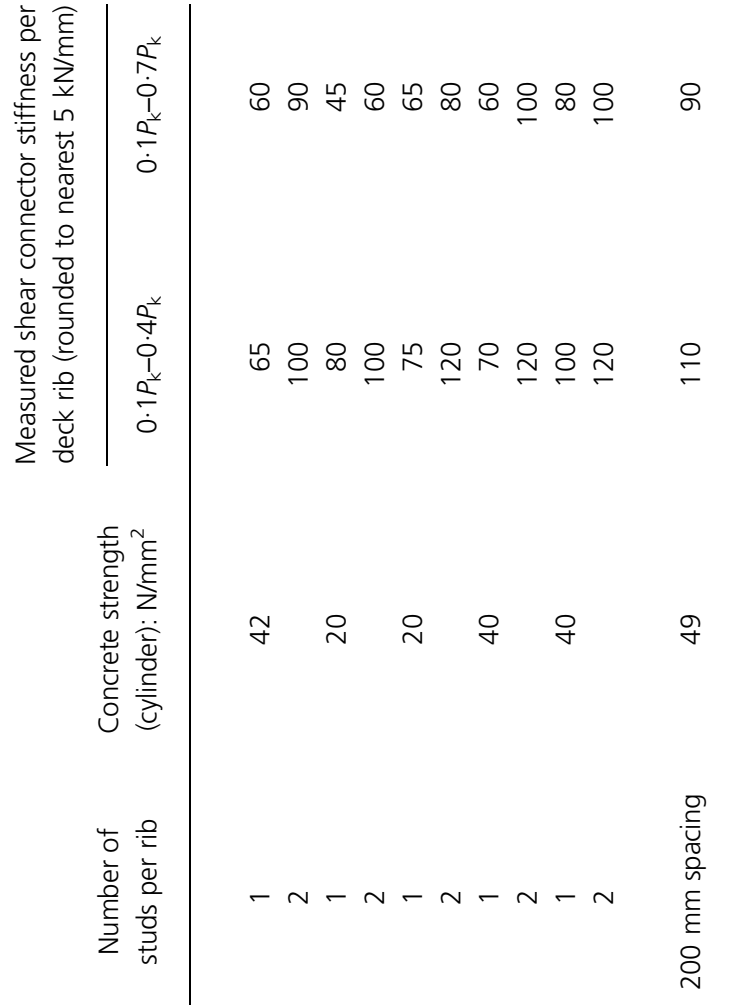

and may be taken as $70 \mathrm{kN} / \mathrm{mm}$ for single shear connectors and $100 \mathrm{kN} / \mathrm{mm}$ for pairs of shear connectors per deck rib. For higher load levels, consistent with propped construction, the elastic stiffness is lower than these values, but for parallel decking the stiffness is higher.

\section{Comparison of theory with tests on composite beams}

To obtain data on the performance of composite beams with less than the minimum degree of shear connection at the ULS according to Eurocode 4 (BSI, 2004), an $11.2 \mathrm{~m}$ span asymmetric beam and $5 \mathrm{~m}$ and $6 \mathrm{~m}$ span symmetric beams were tested at the Universities of Bradford, Stuttgart and Luxembourg as part of the EU project Discco. The tests also gave good data on the serviceability performance of the beams, which is the focus of this paper, and so the test results are summarised here.

\subsection{Test details for $11.2 \mathrm{~m}$ span beam}

A $450 \mathrm{~mm}$ deep asymmetric beam of $11.2 \mathrm{~m}$ span with a ratio of flange areas of 1.5 was tested as being typical of composite fabricated beams of this span. The section comprised a $10 \mathrm{~mm}$ thick top flange and web and $15 \mathrm{~mm}$ thick bottom flange; both flanges were $180 \mathrm{~mm}$ wide and the plates were in S355 steel. The slab was $2.8 \mathrm{~m}$ wide $(=\operatorname{span} / 4)$. The beam was subject to eight-point loading to simulate uniform loading that was progressively increased in seven cycles of loading to determine the effects of slip in the serviceability and ultimate load ranges.

The slab was $150 \mathrm{~mm}$ deep and comprised an $80 \mathrm{~mm}$ deep trapezoidal deck profile, as shown in Figure 3(b). Shear connectors $(125 \mathrm{~mm}$ height and $19 \mathrm{~mm}$ diameter) were welded through the decking at a spacing of $300 \mathrm{~mm}$. The characteristic resistance of the shear connectors was obtained as $75 \mathrm{kN}$ from push tests on this deck profile (for a cylinder strength of $49 \mathrm{~N} / \mathrm{mm}^{2}$ ); this value was down-rated to $65 \mathrm{kN}$ for the measured concrete strength of $29 \mathrm{~N} / \mathrm{mm}^{2}$ in the beam test.

A total of 16 shear connectors were placed from the support to the critical cross-section at the load point at $7 / 16$ of the span, which is equivalent to a degree of shear connection of $33 \%$ for the measured steel yield strength of $410 \mathrm{~N} / \mathrm{mm}^{2}$. According to Eurocode 4 , the minimum degree of shear connection should be $65 \%$ for this beam asymmetry and so the low degree of shear connection in the test could potentially lead to high slips and additional deflections.

A novel system of construction was used to ensure that the loads from the concrete slab were supported by the steel beam to mimic unpropped construction (see Figure 9). This was achieved by bolting channel section out-riggers to the web of the beam so that the outer edge of the decking was supported. The outer props were used to stabilise the beam during the concreting operation but were removed immediately after concreting. The out-riggers were removed when the concrete had 
Structures and Buildings

Volume 170 Issue SB2
Serviceability performance of

steel-concrete composite beams

Lawson, Lam, Aggelopoulos and Nellinger

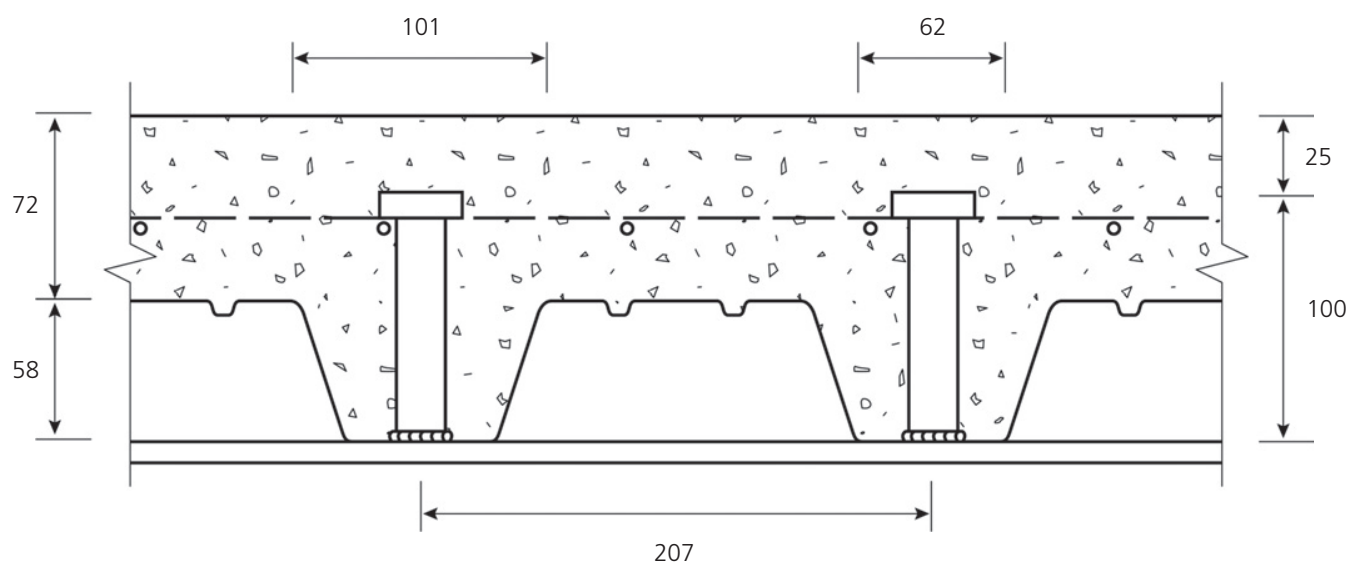

(a)

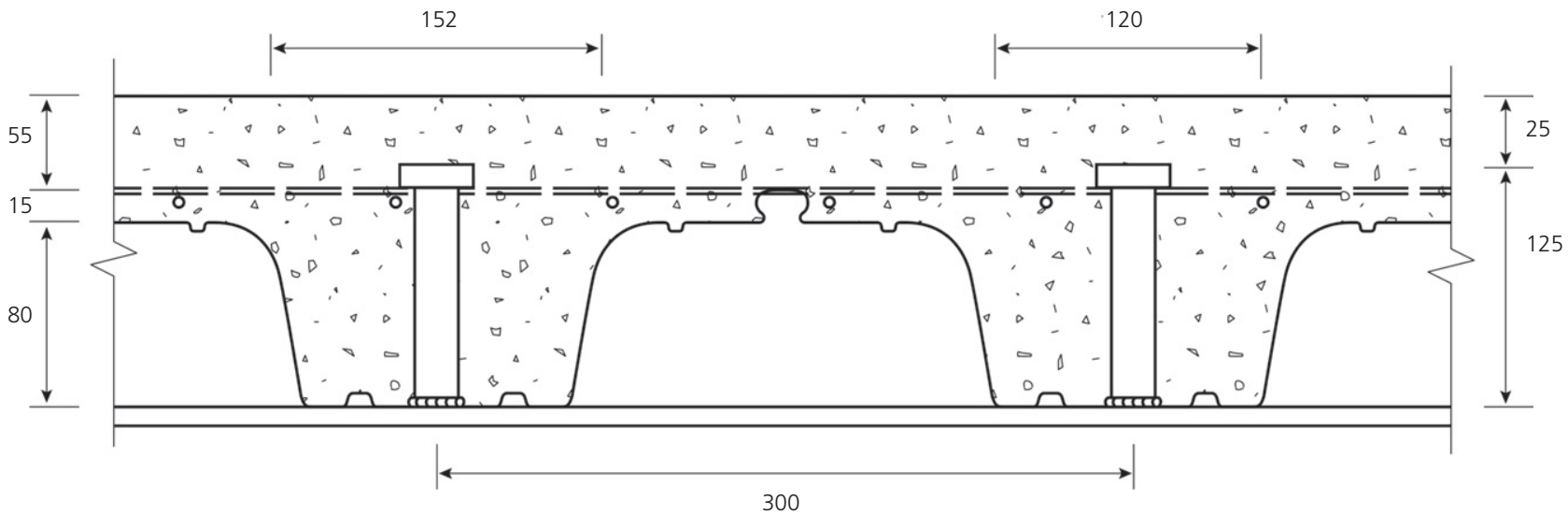

(b)

Figure 3. Details of the trapezoidal deck profiles used in the push tests and beam tests: (a) $58 \mathrm{~mm}$ deep decking profile and $125 \mathrm{~mm}$ high shear connectors; (b) $80 \mathrm{~mm}$ deep decking profile and $125 \mathrm{~mm}$ high shear connectors (all dimensions in $\mathrm{mm}$ )

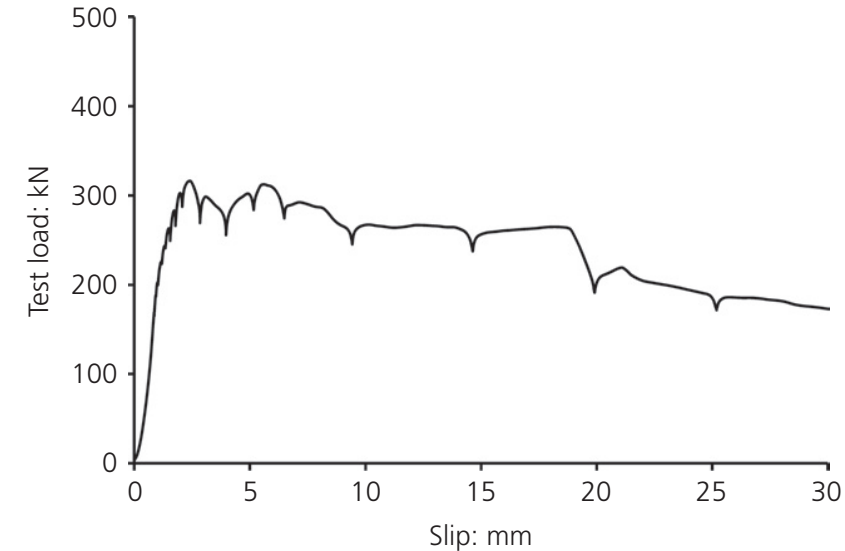

Figure 4. Push-out test results with $80 \mathrm{~mm}$ deep decking using single $125 \mathrm{~mm}$ high shear connectors

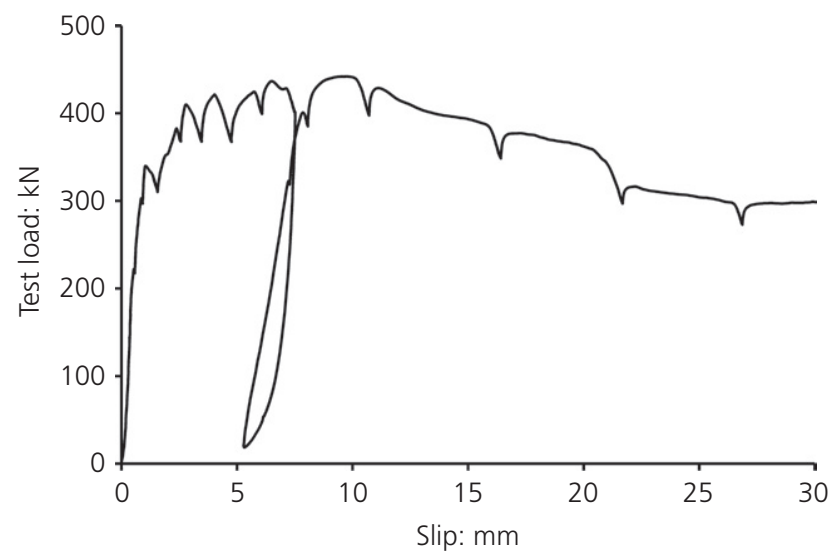

Figure 5. Push test results with $80 \mathrm{~mm}$ deep decking using pairs of shear connectors 


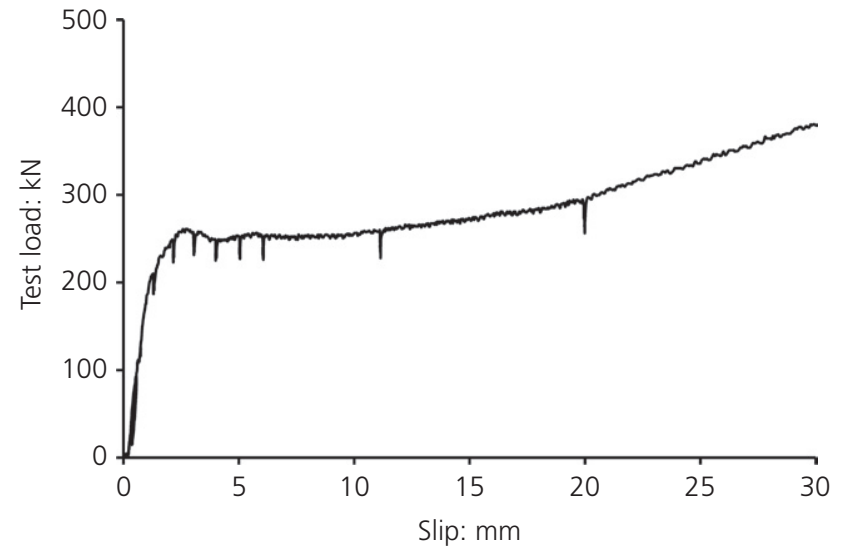

Figure 6. Push test results with $58 \mathrm{~mm}$ deep decking using single shear connectors

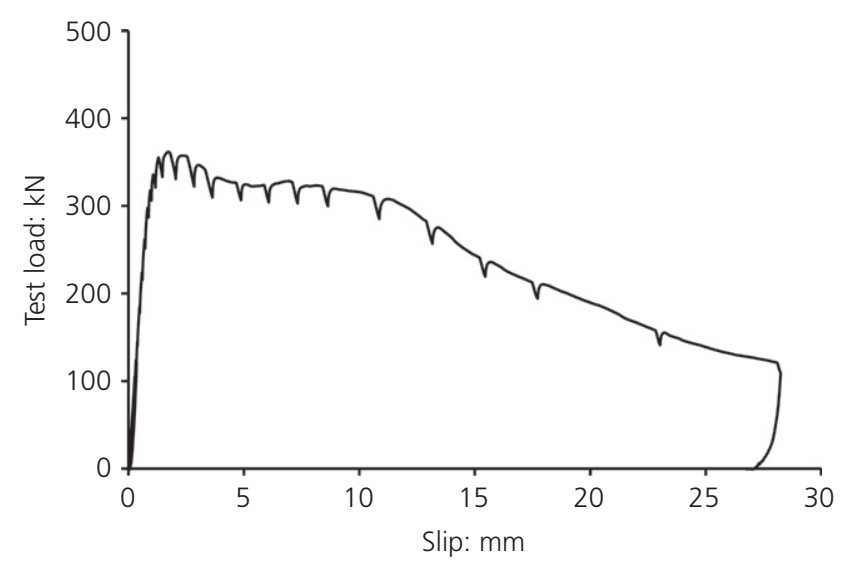

Figure 7. Push test results with $58 \mathrm{~mm}$ deep parallel decking and shear connectors at $200 \mathrm{~mm}$ spacing

gained its full strength. After concreting, the stress in the bottom flange due to the self-weight of the slab and beam was measured at about $29 \%$ of the steel yield strength.

\subsection{Test results for $11 \mathrm{~m}$ span composite beam}

Three cycles of increasing load were applied up to $50 \%$ more than normal service loading and a further four cycles were applied to failure. The maximum displacement at the end of the test was $220 \mathrm{~mm}(=$ span/50). The beam after unloading from the failure load is shown in Figure 10 in which the residual deflection was about $120 \mathrm{~mm}$.

The full load-deflection curve is shown in Figure 11, which indicated that full plasticity had developed at failure. The applied loading at failure was $18.0 \mathrm{kN} / \mathrm{m}^{2}$ plus $3.6 \mathrm{kN} / \mathrm{m}^{2}$ for the self-weight of the slab and beam and spreader beams. This was equivalent to a bending moment of $948 \mathrm{kNm}$. The

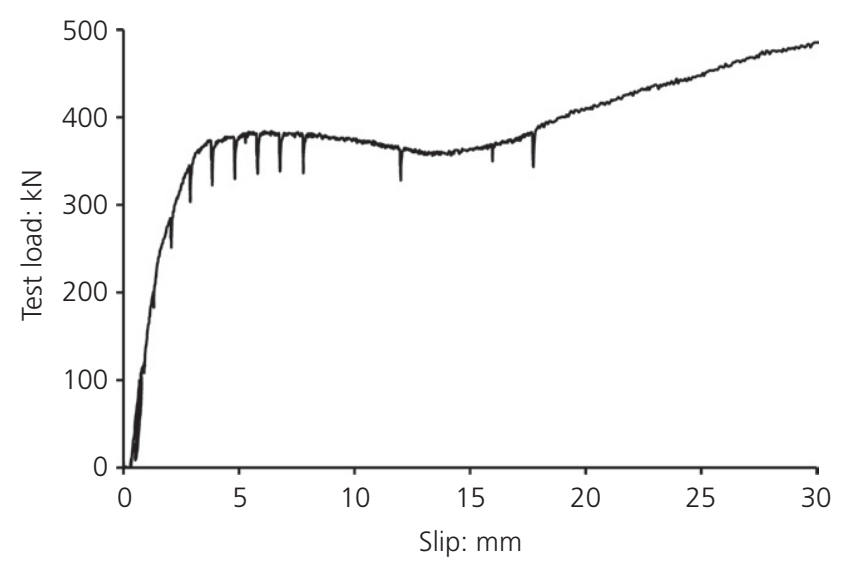

Figure 8. Push test results with $56 \mathrm{~mm}$ deep re-entrant decking using single shear connectors

predicted failure moment was $965 \mathrm{kNm}$, based on measured material strengths, which was only $2 \%$ higher and within the normal margin of acceptance for composite beam tests.

The load-deflection curve for the fifth load cycle up to $12 \mathrm{kN} / \mathrm{m}^{2}$ expressed as a uniformly distributed load over the slab area is shown in Figure 12. This shows linear behaviour up to a load of $10 \mathrm{kN} / \mathrm{m}^{2}$, which is twice the normal service loading and about $55 \%$ of the failure load. A permanent deflection of about $7 \mathrm{~mm}$ was measured after unloading from this cycle, which indicates that irreversible deformation of the shear connectors had occurred.

The load-slip behaviour of the shear connectors is shown in Figure 13. Up to service load levels, the slip in the shear connectors was less than $0.5 \mathrm{~mm}$, and it was observed that slip increased more rapidly at a load of about $7 \mathrm{kN} / \mathrm{m}^{2}$. At a load of $12 \mathrm{kN} / \mathrm{m}^{2}$, the end slip was about $3 \mathrm{~mm}$. The limiting slip of $6 \mathrm{~mm}$ for 'ductile' shear connectors was passed at a load of $15 \mathrm{kN} / \mathrm{m}^{2}$, and from this point, slip increased rapidly to a maximum of $19 \mathrm{~mm}$ at the end of the test, which demonstrated high deformation capacity.

The measured and theoretical deflections were compared for a typical imposed load of $5 \mathrm{kN} / \mathrm{m}^{2}$, for which the measured deflection of the beam was $16 \mathrm{~mm}$ (taking account of the small residual deflection due to bedding-in of the loading system after the first load cycles). Calculations of the effective inertia and end slip are given below, using the following data

$$
\begin{aligned}
& n=E_{\mathrm{s}} / E_{\mathrm{c}}=6(\text { modular ratio for short-term loads) } \\
& A_{\mathrm{s}}=8 \cdot 75 \times 10^{3} \mathrm{~mm}^{2} \\
& A_{\mathrm{c}}=70 \times 2800=196 \times 10^{3} \mathrm{~mm}^{2} \\
& I_{\mathrm{s}}=263 \times 10^{6} \mathrm{~mm}^{4} \\
& \left.I_{\mathrm{c}}=80 \times 10^{6} \mathrm{~mm}^{4} \text { (for } h_{\mathrm{c}}=70 \mathrm{~mm}\right) \\
& y_{\mathrm{s}}=237 \mathrm{~mm} \text { (measured from top flange of steel beam). }
\end{aligned}
$$


Deck profile shape and height (shear connectors welded through the decking in the centre of the rib)

Design shear connector stiffness for $19 \mathrm{~mm}$ diameter shear connectors (expressed per deck rib): kN/mm

\begin{tabular}{lrrrr}
\hline Trapezoidal profiles of 60 to $80 \mathrm{~mm}$ depth & 70 & 60 & 100 & 80 \\
Re-entrant profiles of 50 to $60 \mathrm{~mm}$ depth & 100 & 80 & 120 & 100 \\
Decking parallel to beam & 100 & 80 & Not applicable
\end{tabular}

Table 2. Proposed design values of shear connector stiffness for deflection calculations of unpropped and propped beams

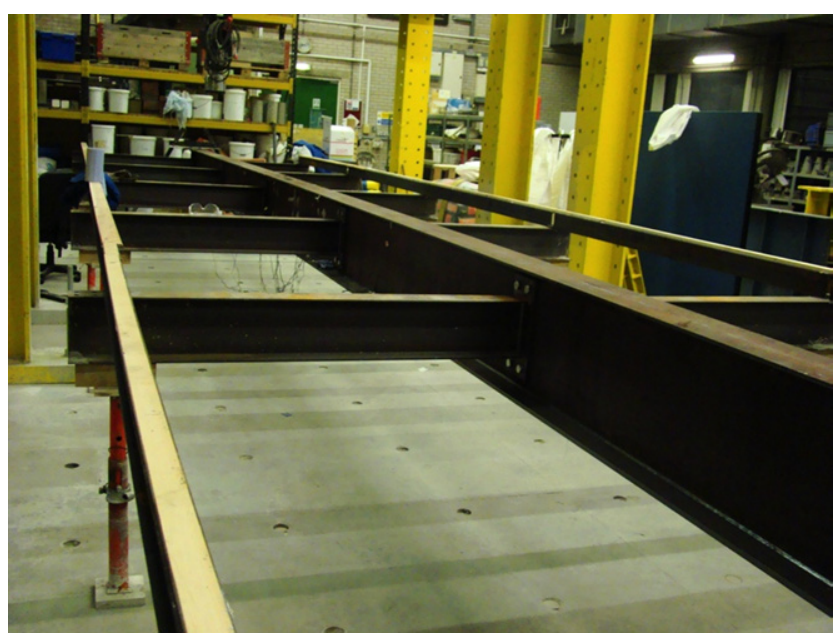

Figure 9. Out-rigger beams used to support the decking to mimic unpropped construction (props removed after assembly)

The composite second moment of area with rigid shear connectors is $I_{\text {comp }}=1131 \times 10^{6} \mathrm{~mm}^{4}$. The shear connector stiffness per unit length is $k / s_{\mathrm{sc}}=70 / 300=0.23 \mathrm{kN} / \mathrm{mm}^{2}$. The effective second moment of area of the composite beam with flexible shear connectors is obtained from Equation 11 as

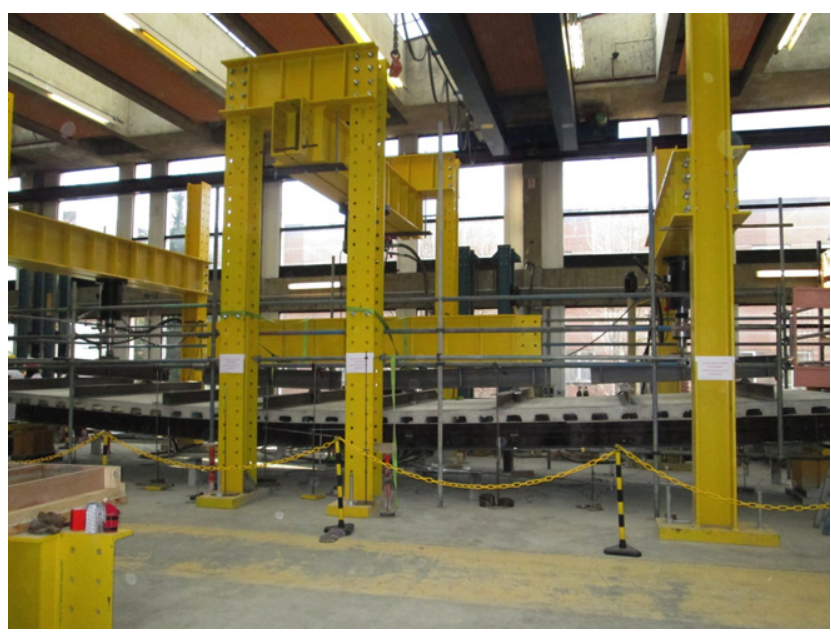

Figure 10. Deflection of composite fabricated beam after unloading from the failure load

The calculated deflection of the fully composite beam with rigid shear connectors is $12 \mathrm{~mm}$ and the deflection of the composite beam with flexible shear connectors (using $k=70 \mathrm{kN} / \mathrm{mm}$ ) is $16.2 \mathrm{~mm}$. Therefore, the additional deflection due to end slip is $35 \%$ of the deflection of the composite

$$
I_{\text {eff }}=263 \times 10^{6}+\frac{80 \times 10^{6}}{6}+\frac{(237+35+80)^{2}\left(\left(196 \times 10^{3}\right) / 6\right)}{\left[1+\left(196 \times 10^{3}\right) /(6 \times 8750)+(\pi / 11200)^{2}(210 / 0 \cdot 23)\left(\left(196 \times 10^{3}\right) / 6\right)\right]}=839 \times 10^{6} \mathrm{~mm}^{4}
$$

The effective inertia $I_{\text {eff }}$ is $74 \%$ of the composite inertia $I_{\text {comp. }}$. For an imposed load of $5 \mathrm{kN} / \mathrm{m}^{2}$, the applied bending moment is $220 \mathrm{kNm}$ and the end slip is obtained from Equation 12 as $0.53 \mathrm{~mm}$. It follows that the maximum force in the shear connectors is $0.53 \times 70=37 \mathrm{kN}$ at this load, and so the shear connectors are still elastic. Using this stiffness, the shear connectors would reach their elastic limit at a load of $9 \cdot 2 \mathrm{kN} / \mathrm{m}^{2}$, which agrees well with the test, and is $51 \%$ of the load acting on the composite beam at failure. beam with rigid shear connectors. The test deflection was approximately $16 \mathrm{~mm}$ at this load, which is in good agreement with the theoretical deflection using this flexibility, as seen in Figure 12.

In Table 3, the test deflections at an equivalent imposed load of $5 \mathrm{kN} / \mathrm{m}^{2}$ are compared with the theory presented in this paper and with the formulae in BS 5950-3 (BSI, 1990) and AISC 360-10 (AISC, 2010). No formulae for additional 


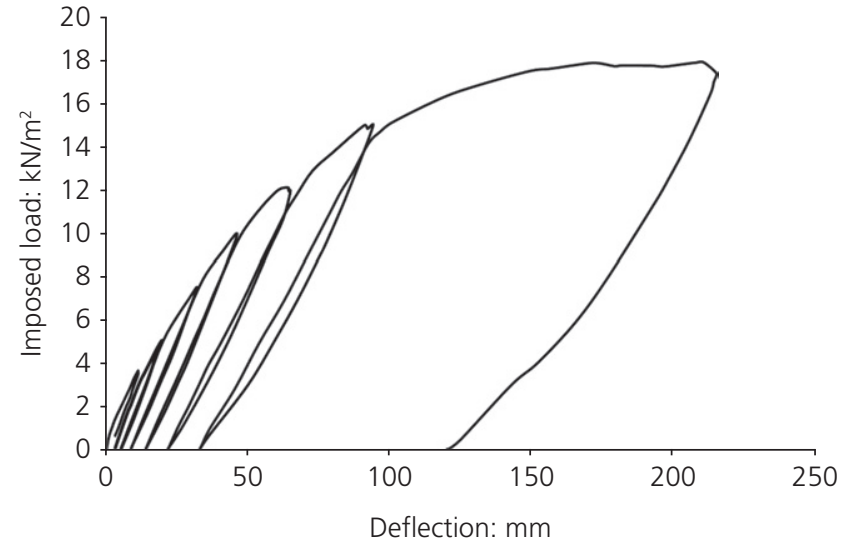

Figure 11. Load-deflection curves of the asymmetric fabricated beam for seven cycles of loading

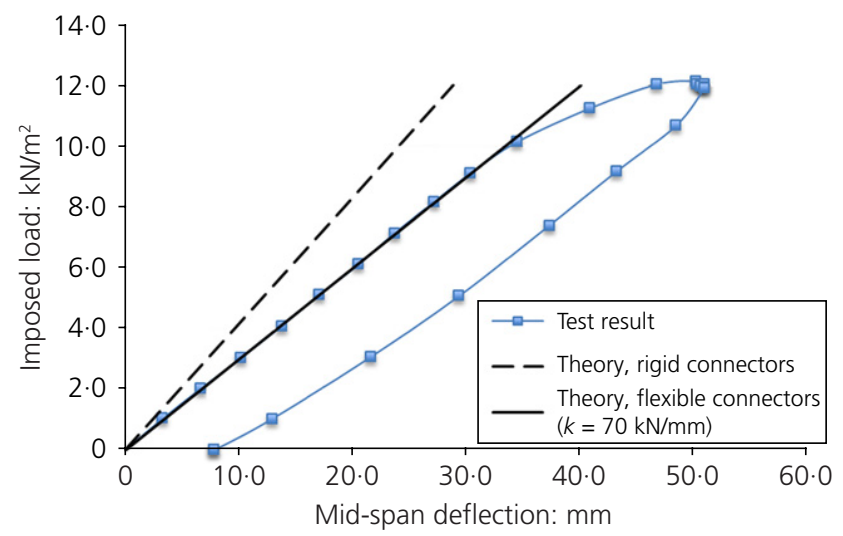

Figure 12. Load-deflection cycle for the asymmetric fabricated beam up to twice working load and comparison with the theory

deflections due to slip are given in Eurocode 4 and so the comparison is only with the deflection for the fully composite stiffness. The effective stiffness was calculated for two shear connector stiffnesses of $k=70$ and $100 \mathrm{kN} / \mathrm{mm}$, and the measured deflection is close to the stiffness corresponding to $k=70 \mathrm{kN} / \mathrm{mm}$.

\subsection{Comparison with short-span beam tests}

A series of $5 \mathrm{~m}$ and $6 \mathrm{~m}$ span beam tests was carried out at the Universities of Stuttgart and Luxembourg in 2014 as part of the same European research project (Discco). The tests on the $5 \mathrm{~m}$ span beams used IPE300 sections and a $58 \mathrm{~mm}$ deep deck profile (see Figure 3(a)) with either single or pairs of $19 \mathrm{~mm}$ diameter shear connectors per deck rib. The tests on the $6 \mathrm{~m}$ span beams used IPE360 sections and an $80 \mathrm{~mm}$ deep deck profile (see Figure 3(b)) with the same shear connector configurations. Only the four tests using $19 \mathrm{~mm}$ diameter shear connectors welded through the decking are presented

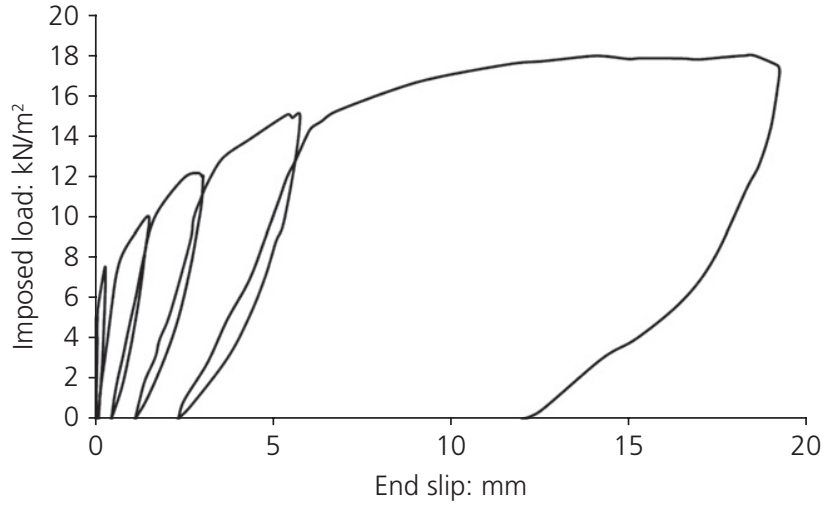

Figure 13. Load-slip curves for all load cycles

here. Other tests were carried out on shear connectors welded through holes cut in the decking and for $22 \mathrm{~mm}$ diameter shear connectors (not reported here).

The tests were subject to two point loads placed at $37 \%$ of the span from the supports. The $6 \mathrm{~m}$ span test is illustrated in Figure 14. The degree of shear connection (from the support to the point load) varied from 18 to $46 \%$ in the four tests based on measured yield strengths of $405 \mathrm{~N} / \mathrm{mm}^{2}$ and $382 \mathrm{~N} / \mathrm{mm}^{2}$ in the IPE300 and IPE360 beams respectively and for concrete cylinder strengths of $44-48 \mathrm{~N} / \mathrm{mm}^{2}$.

A typical graph of the $6 \mathrm{~m}$ span beam in a displacementcontrolled test is shown in Figure 15. A representative point load of $100 \mathrm{kN}$ (total load of $200 \mathrm{kN}$ ) was taken as being in the elastic range and this was about $45 \%$ of the eventual failure load.

The effective stiffness of the composite beams was calculated using $k=70$ or $100 \mathrm{kN} / \mathrm{mm}$ for single and pairs of shear connectors respectively and the ratio of the effective stiffness to the fully composite stiffness was in the range $61-73 \%$. Deflections were calculated at mid-span for the two-point loading case using the effective inertia calculated using Equation 11. Although the theory of effective stiffness was established for uniform loading, it is considered that the effective stiffness is also representative of the two-point load case.

In this study of the serviceability performance of composite beams, two intermediate-span beams were also analysed using the elastic theory presented here. Two tests were carried out at Cambridge University Weerasinghe and McConnel (1999) on $9 \mathrm{~m}$ span composite beams subject to two point loads. The first used decking parallel to the beam and the second used decking perpendicular to the beam. The beams were based on a modified $457 \times 191 \times 60 \mathrm{~kg} / \mathrm{m}$ UB and the section was rolled as slightly asymmetric having a ratio of flange areas of $1 \cdot 1$ (but is treated as essentially symmetric). The deck profile was $60 \mathrm{~mm}$ deep and the theoretical mid-span deflection was calculated for a shear 


\begin{tabular}{|c|c|c|c|c|c|c|}
\hline \multirow{3}{*}{$\begin{array}{l}\text { Degree of shear } \\
\text { connection } \\
\text { in test: \% }\end{array}$} & \multirow{3}{*}{$\begin{array}{c}\text { Measured deflection } \\
\text { in test at } \\
5 \mathrm{kN} / \mathrm{m}^{2}: \mathrm{mm}\end{array}$} & \multirow{3}{*}{$\begin{array}{c}\text { Deflection of } \\
\text { composite beam } \\
\text { without slip: } \mathrm{mm}\end{array}$} & \multirow{2}{*}{\multicolumn{2}{|c|}{$\begin{array}{l}\text { Equation } 11 \text { using shear } \\
\text { connector stiffness of }\end{array}$}} & & \\
\hline & & & & & \multicolumn{2}{|c|}{ Existing code methods } \\
\hline & & & $k=70 \mathrm{kN} / \mathrm{mm}$ & $k=100 \mathrm{kN} / \mathrm{mm}$ & $\begin{array}{l}\text { BS 5950-3 } \\
\text { (BSI, 1990) }\end{array}$ & $\begin{array}{l}\text { AISC 360-10 } \\
\text { (AISC, 2010) }\end{array}$ \\
\hline 33 & $16 \cdot 0$ & $12 \cdot 1$ & $16 \cdot 2$ & $15 \cdot 3$ & $20 \cdot 0$ & $18 \cdot 0$ \\
\hline
\end{tabular}

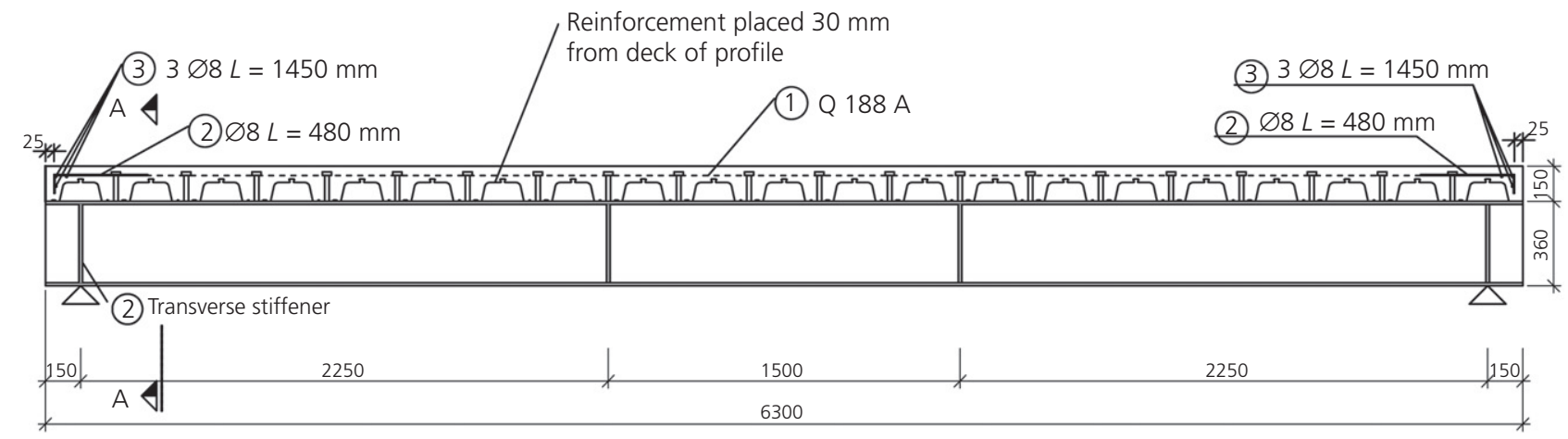

Figure 14. Test on $6 \mathrm{~m}$ span composite IPE360 beam with single shear connectors per $80 \mathrm{~mm}$ deep deck rib (load points at $2.25 \mathrm{~m}$ from the supports); dimensions in $\mathrm{mm}$

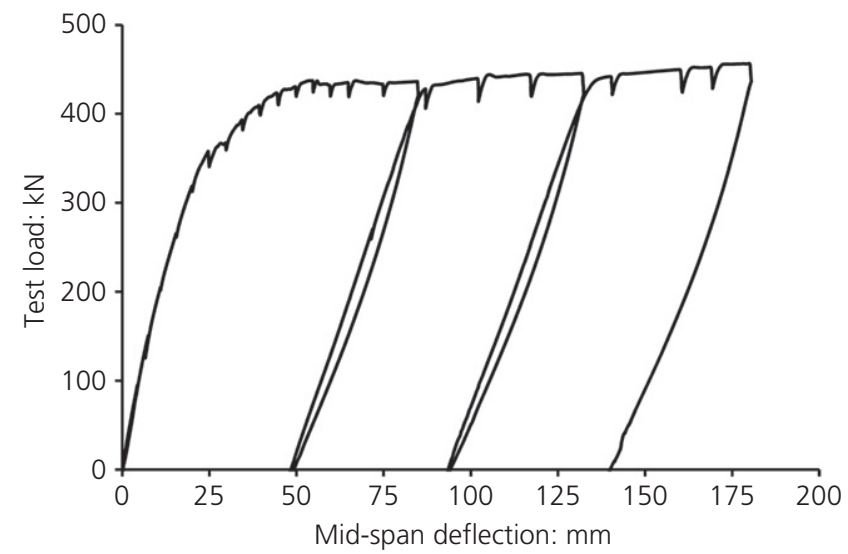

Figure 15. Load-deflection curve for tests on $6 \mathrm{~m}$ span composite IPE360 beam with single shear connectors per $80 \mathrm{~mm}$ deep deck rib

connector stiffness of $70 \mathrm{kN} / \mathrm{mm}$ for transverse decking and $100 \mathrm{kN} / \mathrm{m}$ for parallel decking. Again, a point load of $100 \mathrm{kN}$ was used in these comparisons, which was about $45 \%$ of the failure load.
Table 4 shows a comparison of the measured and theoretical deflections for all six tests: the comparison with the elastic theory using a representative shear connector stiffness is very good. End slips at this load level were measured as being small (approximately $0.3 \mathrm{~mm}$ ), although the theoretical slip in the tests was calculated as being $0 \cdot 6-0 \cdot 8 \mathrm{~mm}$.

Table 4 also shows that the code methods lead to slightly higher deflections for the low degrees of shear connection in the tests. The BS 5950-3 (BSI, 1990) method overpredicts the test deflection of the beams by only $3-10 \%$ and is accurate for the shorter span cases. The AISC 360-10 (AISC, 2010) formula has a similar range of accuracy.

\section{Sensitivity study on deflections of composite beams of 6-18 $\mathrm{m}$ span}

\subsection{Additional deflection due to partial shear connection}

To determine the effects of partial shear connection on deflections, a parametric study was carried out for beams with spans of 6-18 m using typical section sizes and common design 


\begin{tabular}{|c|c|c|c|c|c|c|c|}
\hline \multirow[b]{3}{*}{ Shear connectors ${ }^{a}$} & \multirow[b]{3}{*}{$\eta: \%^{\mathrm{b}}$} & \multirow[b]{3}{*}{$\begin{array}{l}\text { Effective stiffness, } l_{\text {eff }} \\
\text { (Equation 11): } m^{4}\end{array}$} & \multirow[b]{3}{*}{$l_{\text {eff }} / l_{\text {comp }}$} & \multicolumn{4}{|c|}{ Deflection: $\mathrm{mm}$} \\
\hline & & & & \multicolumn{2}{|c|}{ At $P=100 \mathrm{kN}^{\mathrm{c}}$} & \multicolumn{2}{|c|}{ Comparison with code methods } \\
\hline & & & & Test & $\begin{array}{l}\text { Theory } \\
\text { (Equation 11) }\end{array}$ & $\begin{array}{l}\text { BS 5950-3 } \\
\text { (BSI, 1990) }\end{array}$ & $\begin{array}{l}\text { AISC 360-10 } \\
\text { (AISC, 2010) }\end{array}$ \\
\hline \multicolumn{8}{|c|}{ IPE360 section, $6 \mathrm{~m}$ span, $150 \mathrm{~mm}$ slab depth, $80 \mathrm{~mm}$ deck profile } \\
\hline Single at $300 \mathrm{~mm}$ & 18 & $366 \times 10^{6}$ & 0.61 & $10 \cdot 5$ & $10 \cdot 7$ & $10 \cdot 8$ & $11 \cdot 2$ \\
\hline Pairs at $300 \mathrm{~mm}$ & 21 & $405 \times 10^{6}$ & $0 \cdot 67$ & $9 \cdot 2$ & $9 \cdot 6$ & $10 \cdot 7$ & $10 \cdot 7$ \\
\hline \multicolumn{8}{|c|}{ IPE300 section, $5 \mathrm{~m}$ span,130 mm slab depth, $58 \mathrm{~mm}$ deck profile } \\
\hline Single at $207 \mathrm{~mm}$ & 23 & $210 \times 10^{6}$ & 0.64 & $10 \cdot 2$ & $10 \cdot 5$ & $11 \cdot 0$ & 11.7 \\
\hline Pairs at $207 \mathrm{~mm}$ & 46 & $240 \times 10^{6}$ & 0.73 & $9 \cdot 3$ & $9 \cdot 2$ & $9 \cdot 7$ & 8.8 \\
\hline \multicolumn{8}{|c|}{ Asymmetric section based on $457 \times 191$ UB, $9 \mathrm{~m}$ span, $130 \mathrm{~mm}$ slab depth, $60 \mathrm{~mm}$ deck profile } \\
\hline Single at $300 \mathrm{~mm}$ & 37 & $725 \times 10^{6}$ & $0 \cdot 71$ & $17 \cdot 2$ & $17 \cdot 0$ & $17 \cdot 7$ & $16 \cdot 8$ \\
\hline At $350 \mathrm{~mm}$ - parallel decking & 32 & $736 \times 10^{6}$ & 0.74 & $16 \cdot 5$ & $16 \cdot 7$ & $18 \cdot 2$ & 17.9 \\
\hline
\end{tabular}

Table 4. Comparison of serviceability test results on 5, 6 and $9 \mathrm{~m}$ span beams with the theory and code methods

\begin{tabular}{lll}
\hline Span: $\mathrm{m}$ & Beam size & Common data \\
\hline $6-7$ & IPE270 & Slab width $=$ span $/ 4$ \\
$9-10$ & IPE400 & Slab depth $=130 \mathrm{~mm}$ \\
$11-12 \cdot 5$ & IPE500 & Profile height $=60 \mathrm{~mm}$ \\
$13 \cdot 5-15$ & IPE600 & Steel grade $=\mathrm{S} 355$ \\
$17-18$ & IPE750-137 & Shear connectors at $300 \mathrm{~mm}$ spacing \\
& & Shear resistance, $P_{\mathrm{d}}=70 \mathrm{kN}$ \\
& & Modular ratio, $E_{\mathrm{s}} / E_{\mathrm{c}}=10$
\end{tabular}

Table 5. Beam sizes investigated in the sensitivity study on deflections due to partial shear connection

parameters. The beam sizes and typical spans for two span/depth ratios are presented in Table 5.

The increase in deflection using the effective inertia in Equation 11 is presented in Table 6 for these beams with two span/depth ratios and two degrees of shear connection. Single shear connectors at $300 \mathrm{~mm}$ spacing with an elastic stiffness of $70 \mathrm{kN} / \mathrm{mm}$ and a shear resistance of $70 \mathrm{kN}$ are consistent with $39 \%$ shear connection at the ULS to Eurocode 4 (BSI, 2004). Pairs of shear connectors with a stiffness of $k=100 \mathrm{kN} / \mathrm{mm}$ per deck rib and combined shear resistance of $100 \mathrm{kN}$ leads to $56 \%$ shear connection. Also presented in
Table 6 (values in brackets) are the deflections obtained from Equation 1, which is given in the former code BS 5950-3 (BSI, 1990).

It is apparent that the additional deflection due to the flexibility of the shear connectors reduces with beam span because the proportionate stiffness of the composite section to the steel section reduces with span. The proportionate increase in deflection due to end slip also decreases with the beam span/depth ratio as shear becomes more significant. Comparisons with Equation 1 (from BS 5950-3 (BSI, 1990)) are also listed in the table, based on the degree of shear connection. It can be seen that the comparison with the elastic theory is reasonably close for shorter span beams with a span/depth ratio of 22, but Equation 1 becomes increasingly conservative for longer span beams with higher span/depth ratios.

\subsection{Finite-element analysis of composite beams}

The generalised FE package Ansys was used to model the composite beams. The FE model was built using shell elements for the steel section and solid elements for the slab. The shear connectors were modelled using non-linear spring elements. The FE model mesh is shown in Figure 16. The deck ribs were modelled with a reduced stiffness (elastic modulus of $E_{\mathrm{c}} / 10$ ) compared with the rest of the slab. This was done to avoid overestimating the system stiffness, since the contribution from the concrete ribs is already accounted for in the load-slip characteristics which are input to the spring stiffness only. Half 
Beam span/depth, $L / h=22$

Shear connector spacing
Beam span/depth, $L / h=25$

\begin{tabular}{ccc}
\hline & \multicolumn{2}{c}{ Shear connector spacing } \\
\cline { 2 - 3 }$I_{\text {comp }} / I_{\mathrm{s}}$ & Pairs at 300 mm & Singles at 300 mm \\
\hline $4 \cdot 1$ & $30 \%(41 \%)$ & $41 \%(57 \%)$ \\
$3 \cdot 3$ & $22 \%(31 \%)$ & $30 \%(42 \%)$ \\
$3 \cdot 0$ & $18 \%(27 \%)$ & $25 \%(36 \%)$ \\
$2 \cdot 8$ & $16 \%(24 \%)$ & $22 \%(33 \%)$ \\
$2 \cdot 7$ & $11 \%(23 \%)$ & $16 \%(30 \%)$
\end{tabular}

shear connectors using Equation 11. Values in brackets are from Equation 1 according to BS 5950-3 (BSI, 1990)
Table 6. Increase in deflection (expressed as a percentage relative to composite beam with rigid shear connectors) of symmetric sections due to partial shear connection relative to that with rigid

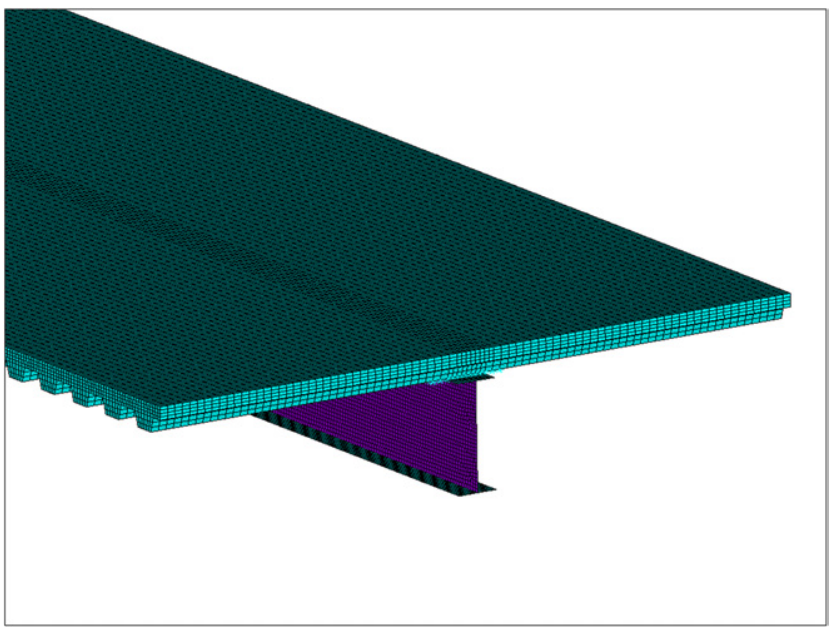

Figure 16. FE model of the composite beam showing the mesh detail

the beam span was modelled because of symmetry, and the ends of the beams were taken as simply supported.

The FE model was first verified against the long-span composite beam test. The material model assumed for the steel beam was bilinear (linear up to the measured yield strength and then a plateau with a strain-hardening gradient of E/100). A trilinear model was used for modelling the concrete, which does not capture the unloading behaviour occurring at strains higher than $0 \cdot 2 \%$, but this concrete strain was not exceeded due to the low degrees of shear connection. The shear connectors (springs) were modelled in a bilinear form with an elastic stiffness of $70 \mathrm{kN} / \mathrm{mm}$ and a plastic plateau at a shear connector resistance of $70 \mathrm{kN}$ based on push-out test results.

The load-deflection graph obtained from the model in comparison with the beam test results is shown in Figure 17: the

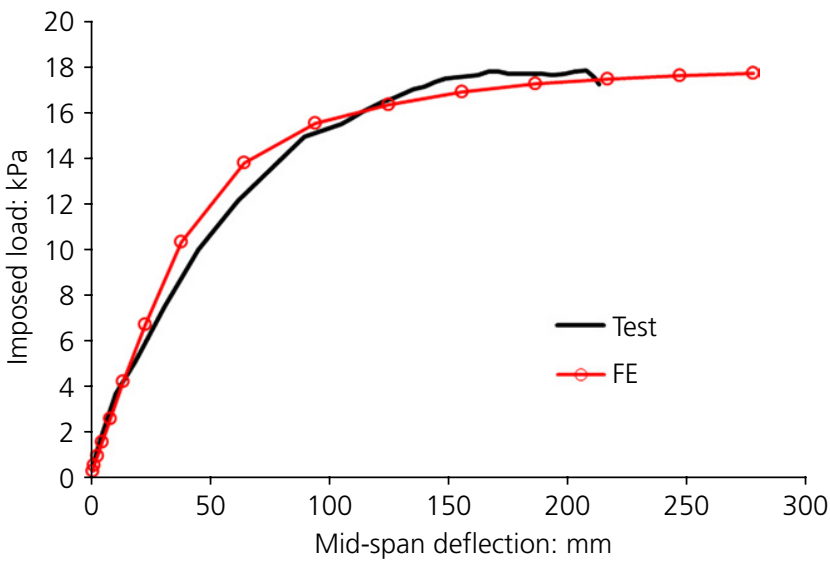

Figure 17. Load-deflection curve for the $11.2 \mathrm{~m}$ span asymmetric fabricated beam obtained from the test and FE simulations

data are in close agreement in the initial load range and close to failure. The load-slip graph is shown in Figure 18, which shows that the end slip is lower than the FE prediction in the initial load range. These results demonstrate the adequacy of the FE model, which was then used to carry out a parametric study of the serviceability performance of a range of beams of 6-18 m.

Beams using rolled IPE270 to IPE600 sections with spans of $6-15 \mathrm{~m}$ were modelled. An imposed load of $0 \cdot 3 P_{\mathrm{Ed}, \mathrm{pl}}$ was taken as being typical of the service load for unpropped composite beams, whereas a load of $0.5 P_{\mathrm{Ed}, \mathrm{pl}}$ was used for propped composite beams. Table 7 shows that, for unpropped beams, the end slip varies only slightly with beam span and does not exceed $0.7 \mathrm{~mm}$ at this load, which is within the elastic range. However, for propped beams, the end slip at a load of $0 \cdot 5 P_{\text {Ed,pl }}$ increased from $1 \cdot 1$ to $1.5 \mathrm{~mm}$ for 9 to $15 \mathrm{~m}$ spans, which is the post-elastic range and would lead to higher deflections due to partial shear connection. 


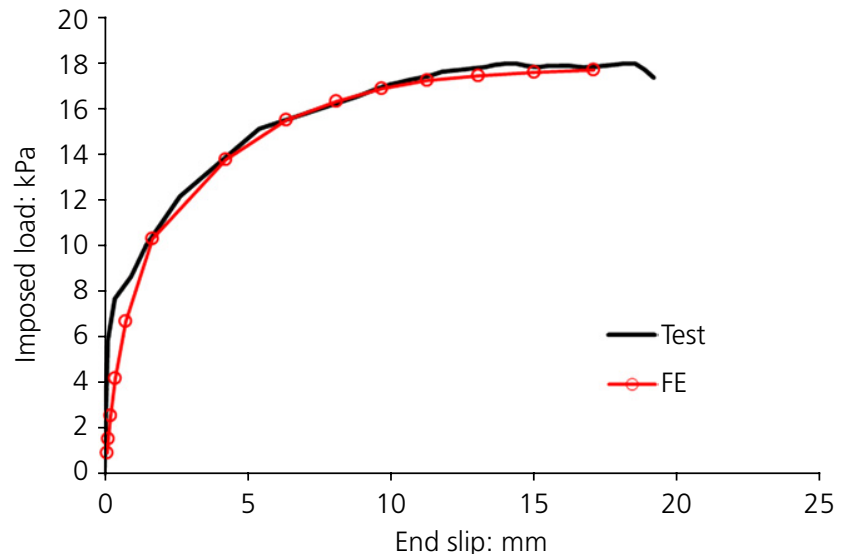

Figure 18. Load-end slip curve for the $11.2 \mathrm{~m}$ span asymmetric fabricated beam obtained from the test and FE simulations

Table 7 also compares the FE results with the elastic theory presented in this paper for the two load levels. The values for unpropped beams and for shorter span propped beams are within $10 \%$ and the difference is likely to be more in the FE modelling of the stiffness of the shear connection system than in the theory. The FE analysis leads to higher deflections for longer span propped beams due to the plasticity developed in the shear connectors.

\subsection{Sensitivity study on minimum degree of shear connection}

The FE analyses were extended to consider at what point a limiting slip of $1 \mathrm{~mm}$ is exceeded for beams of $6-15 \mathrm{~m}$ span with a span/depth ratio in the range 22-25. The working loads for these beams were taken as a proportion of their plastic bending resistance for the particular degree of shear connection. The analyses were repeated by adjusting the degree of shear connection so that the end slip did not exceed $1 \mathrm{~mm}$.

The serviceability load in this analysis was first determined from $\left(M_{\mathrm{pl}}-1 \cdot 35 M_{\mathrm{sw}}\right) / 1 \cdot 5$ for unpropped beams and $M_{\mathrm{pl}} / 1 \cdot 5$ for propped beams, where $M_{\mathrm{pl}}$ is the plastic resistance of the beam for partial shear connection and $M_{\mathrm{sw}}$ is the moment due to the self-weight of the beam and slab. This leads to serviceability loads that are higher than $0 \cdot 3 P_{\mathrm{Ed}, \mathrm{pl}}$ and $0 \cdot 5 P_{\mathrm{Ed}, \mathrm{pl}}$ where $P_{\mathrm{Ed}, \mathrm{pl}}$ is be load corresponding to the beam plastic bending resistance. The results in terms of the minimum degree of shear connection for $1 \mathrm{~mm}$ end slip are presented in Table 8 for symmetric beams.

It is argued that the statistical likelihood of repeated loading of the magnitude of the full serviceability load is low and therefore the cumulative effects of slip will not be significant. Therefore, the load at which the slip was calculated was taken as $0 \cdot 8\left(M_{\mathrm{pl}}-1 \cdot 35 M_{\mathrm{sw}}\right) / 1 \cdot 5$ for unpropped beams and $0 \cdot 8 M_{\mathrm{pl}} / 1 \cdot 5$ for propped beams. This leads to serviceability loads closer to $0.3 P_{\mathrm{Ed}, \mathrm{pl}}$ and $0.5 P_{\mathrm{Ed}, \mathrm{pl}}$ for unpropped and propped beams respectively. For symmetric beams, the minimum degree of shear connection for a $1 \mathrm{~mm}$ slip limit at the SLS was found to be in the range of $0 \cdot 29-0 \cdot 47$ for propped beams and $0 \cdot 23-0 \cdot 32$ for unpropped beams (i.e. about $20 \%$ less than for propped beams).

Based on these results for a maximum serviceability slip of $1 \mathrm{~mm}$, it is proposed that the cut-off in the minimum degree of shear connection for symmetric composite beams could be taken as $0 \cdot 3$ for unpropped beams and $0 \cdot 4$ for propped beams. The 0.4 minimum limit is the same as for the existing shear connection rules in Eurocode 4, and so a relaxation in the minimum degree of shear connection is made only for unpropped beams.

\begin{tabular}{|c|c|c|c|c|c|c|c|}
\hline \multirow[b]{2}{*}{ Span: m } & \multirow[b]{2}{*}{ Section } & \multirow[b]{2}{*}{$P_{\mathrm{Ed}, \mathrm{pl}}: \mathrm{kN} / \mathrm{m}$} & \multirow[b]{2}{*}{ Method } & \multicolumn{2}{|c|}{ Beam Load of $0 \cdot 3 P_{\mathrm{Ed}, \mathrm{pl}}$} & \multicolumn{2}{|c|}{ Beam Load of $0.5 P_{\mathrm{Ed}, \mathrm{pl}}$} \\
\hline & & & & $w: \mathrm{mm}$ & $\mathrm{s}: \mathrm{mm}$ & $w: \mathrm{mm}$ & s: $\mathrm{mm}$ \\
\hline \multirow[t]{2}{*}{6} & IPE270 & $68 \cdot 6$ & $\mathrm{FE}$ & $11 \cdot 4$ & 0.53 & $19 \cdot 0$ & $0 \cdot 88$ \\
\hline & & & Theory & $10 \cdot 6$ & 0.55 & $18 \cdot 2$ & 0.91 \\
\hline \multirow[t]{2}{*}{9} & IPE400 & $70 \cdot 4$ & $\mathrm{FE}$ & $17 \cdot 4$ & $0 \cdot 60$ & $29 \cdot 5$ & $1 \cdot 12$ \\
\hline & & & Theory & $16 \cdot 0$ & 0.61 & $26 \cdot 6$ & 1.02 \\
\hline \multirow[t]{2}{*}{12} & IPE500 & $64 \cdot 9$ & $\mathrm{FE}$ & $24 \cdot 5$ & 0.63 & $41 \cdot 7$ & $1 \cdot 28$ \\
\hline & & & Theory & $22 \cdot 0$ & 0.64 & $36 \cdot 7$ & 1.06 \\
\hline \multirow[t]{2}{*}{15} & IPE600 & $64 \cdot 1$ & $\mathrm{FE}$ & $32 \cdot 3$ & 0.66 & $55 \cdot 5$ & 1.48 \\
\hline & & & Theory & $29 \cdot 0$ & 0.67 & $48 \cdot 4$ & $1 \cdot 12$ \\
\hline
\end{tabular}

Table 7. Deflection $(w)$ and end slip (s) of composite beams at $30 \%$ and $50 \%$ of the maximum load acting on the beam determined from its plastic bending resistance $\left(P_{\mathrm{Ed}, \mathrm{pl}}\right)$ based on FE results and elastic theory (Equation 11) 
Unpropped beams

Propped beams

\begin{tabular}{|c|c|c|c|c|c|c|}
\hline \multirow[b]{2}{*}{ Span: $m$} & \multirow[b]{2}{*}{ Beam (in S355 steel) } & \multirow[b]{2}{*}{$N_{s c}^{a}$} & & \\
\hline & & & $0 \cdot 8\left(M_{p l}-1.35 M_{s w}\right) / 1.5$ & $\left(M_{\mathrm{pl}}-1 \cdot 35 M_{\mathrm{sw}}\right) / 1 \cdot 5$ & $0 \cdot 8 M_{\mathrm{pl}} / 1 \cdot 5$ & $M_{\mathrm{pl}} / 1 \cdot 5$ \\
\hline \multirow[t]{2}{*}{6} & IPE270 & 1 & 0.26 & $0 \cdot 37$ & 0.29 & 0.40 \\
\hline & & 2 & 0.32 & 0.43 & 0.37 & 0.48 \\
\hline \multirow[t]{2}{*}{9} & IPE400 & 1 & 0.27 & 0.37 & 0.34 & 0.46 \\
\hline & & 2 & $0 \cdot 32$ & 0.46 & 0.39 & 0.53 \\
\hline \multirow[t]{2}{*}{12} & IPE500 & 1 & 0.26 & $0 \cdot 37$ & 0.37 & 0.48 \\
\hline & & 2 & 0.32 & 0.43 & 0.43 & 0.56 \\
\hline \multirow[t]{2}{*}{15} & IPE600 & 1 & 0.23 & 0.35 & 0.38 & 0.50 \\
\hline & & 2 & $0 \cdot 30$ & 0.43 & 0.47 & 0.55 \\
\hline
\end{tabular}

${ }^{a}$ Number of shear connectors per deck rib; shear connector stiffness of $70 \mathrm{kN} / \mathrm{mm}$ for single shear connectors and $100 \mathrm{kN} / \mathrm{mm}$ for pairs of shear connectors

Table 8. Minimum degree of shear connection for symmetric beams for $1 \mathrm{~mm}$ slip limit at different serviceability loads

\begin{tabular}{|c|c|c|c|c|c|c|}
\hline \multirow[b]{2}{*}{ Span: m } & \multirow{2}{*}{$\begin{array}{l}\text { Asymmetric beam based on } \\
\text { original section (in S355 steel) }\end{array}$} & \multirow[b]{2}{*}{$N_{\text {SC }}{ }^{a}$} & \multicolumn{2}{|c|}{ Unpropped beams } & \multicolumn{2}{|c|}{ Propped beams } \\
\hline & & & $0.8\left(M_{\mathrm{pl}}-1 \cdot 35 M_{\mathrm{sw}}\right) / 1 \cdot 5$ & $\left(M_{p l}-1 \cdot 35 M_{s w}\right) / 1 \cdot 5$ & $0 \cdot 8 M_{p l} / 1 \cdot 5$ & $M_{\mathrm{pl}} / 1 \cdot 5$ \\
\hline \multirow[t]{2}{*}{6} & \multirow[t]{2}{*}{ IPE270 with $A_{\mathrm{fb}} / A_{\mathrm{ft}}=3$} & 1 & $0 \cdot 37$ & 0.48 & 0.40 & 0.51 \\
\hline & & 2 & 0.43 & 0.53 & 0.48 & 0.59 \\
\hline \multirow[t]{2}{*}{9} & \multirow[t]{2}{*}{ IPE400 with $A_{\mathrm{fb}} / A_{\mathrm{ft}}=3$} & 1 & $0 \cdot 39$ & 0.54 & $0 \cdot 46$ & $0 \cdot 61$ \\
\hline & & 2 & 0.46 & 0.60 & 0.53 & 0.68 \\
\hline \multirow[t]{2}{*}{12} & \multirow[t]{2}{*}{ IPE500 with $A_{\mathrm{fb}} / A_{\mathrm{ft}}=3$} & 1 & $0 \cdot 38$ & 0.51 & $0 \cdot 48$ & 0.60 \\
\hline & & 2 & 0.43 & 0.59 & 0.53 & 0.69 \\
\hline \multirow[t]{2}{*}{15} & \multirow[t]{2}{*}{ IPE600 with $A_{\mathrm{fb}} / A_{\mathrm{ft}}=3$} & 1 & $0 \cdot 38$ & 0.51 & $0 \cdot 50$ & $0 \cdot 64$ \\
\hline & & 2 & 0.43 & 0.58 & 0.58 & 0.73 \\
\hline
\end{tabular}

${ }^{\mathrm{a}}$ Number of shear connectors per deck rib; shear connector stiffness of $70 \mathrm{kN} / \mathrm{mm}$ for single shear connectors and $100 \mathrm{kN} / \mathrm{mm}$ for pairs of shear connectors

Table 9. Minimum degree of shear connection for asymmetric beams based on original IPE section with flange areas of 3:1 for $1 \mathrm{~mm}$ slip limit at different serviceability loads

The same approach was used for asymmetric composite beams with a maximum ratio of flange areas of $3: 1$ in which the thickness of the original top flange was multiplied by 0.5 and the thickness of the original bottom flange was multiplied by 1.5 in order to keep to the same cross-sectional area as the original beam.

In this case, the minimum degree of shear connection was higher than for symmetric sections. Results of these analyses are presented in Table 9. For propped beams, the minimum degree of shear connection is in the range $0 \cdot 40-0.58$ and for unpropped beams it is in the range $0 \cdot 37-0 \cdot 46$. It follows that the minimum degree of shear connection of an unpropped beam is about $10 \%$ less than for a propped beam.

As a good approximation for unpropped beams, the minimum limit on the degree of shear connection to control slip at the SLS may be taken as

15. $\operatorname{Min} \eta=0 \cdot 2+0 \cdot 1\left(A_{\mathrm{fb}} / A_{\mathrm{ft}}\right) \geq 0 \cdot 3$

Similarly, for propped beams, the minimum limit on the degree of shear connection to control slip at the SLS may be 
taken as

\section{6. $\operatorname{Min} \eta=0 \cdot 3+0 \cdot 1\left(A_{\mathrm{fb}} / A_{\mathrm{ft}}\right) \geq 0 \cdot 4$}

These cut-off values should be applied to the general rules for the minimum degree of shear connection at the ULS, irrespective of an limiting end slip of $6 \mathrm{~mm}$ or $10 \mathrm{~mm}$.

\section{Conclusions}

From a series of seven short- and long-span beam tests it has been shown that the effective second moment of area of a composite beam with flexible shear connectors may be calculated using Equation 11 as a function of the shear connector stiffness, $k$, and longitudinal spacing, $s_{\mathrm{sc}}$.

For unpropped beams, by comparison with long-span beam tests, it was shown that deflections may be calculated with reasonable accuracy using $k=70 \mathrm{kN} / \mathrm{mm}$ for single shear connectors per deck rib and $k=100 \mathrm{kN} / \mathrm{mm}$ for pairs of shear connectors per deck rib. The end slip may be presented as a function of the inertias of the composite section, $I_{\text {comp }}$, and the steel section, $I_{\mathrm{s}}$, as in Equation 12.

Comparisons of the additional deflections due to partial shear connection between the tests and the former BS 5950-3 (BSI, 1990) and AISC 360-10 (AISC, 2010) were found to be reasonably accurate for the shorter span beams, but conservative by about $20 \%$ for the $11 \mathrm{~m}$ span asymmetric beam test with $33 \%$ shear connection. Although this is work in progress, it is proposed that the former BS 5950-3 (BSI, 1990) method may be modified to improve its accuracy for long-span beams by taking into account the span/depth ratio of the beam. Therefore, the deflection of unpropped composite beams may be determined with reasonable accuracy from

$$
w=w_{\text {comp }}+0 \cdot 3[20 /(L / h)]^{0.5}(1-\eta)\left(w_{\mathrm{s}}-w_{\text {comp }}\right)
$$

where $L$ is the beam span, $h$ is the steel beam height, $\eta$ is the degree of shear connection at the ultimate limit state and $w_{\mathrm{s}}$ and $w_{\text {comp }}$ are the deflections using beam stiffnesses $I_{\mathrm{s}}$ and $I_{\text {comp }}$ respectively at the serviceability loads.

A minimum cut-off in the degree of shear connection is required to control the end slip at the serviceability limit state so that cumulative deflections do not occur under repeated loading. For unpropped beams, it is proposed that this minimum limit is taken as in Equation 15.

\section{Acknowledgement}

The testing was performed at the Universities of Bradford, Stuttgart and Luxembourg under the RFCS project Discco 'Development of improved shear connection rules in composite beams' RFSR-CT-2012-00030.

\section{REFERENCES}

AISC (American Institute of Steel Construction) (2010) AISC 360-10: Specification for Structural Steel Buildings, Manual of Steel Construction. American Institute of Steel Construction, Chicago, IL, USA.

Aribert JM (1997) Analyse et formulation pratique de l'influence de la nuance de l'acier du profile sur le degree minimum de connexion partielle d'une poutre mixte. Construction Métallique 3(3): 39-55 (in French).

BSI (1990) BS 5950: Structural use of steelwork in buildings, Part 3 design in composite construction. Section 3.1: Code of practice for design of simple and continuous composite beams, 1990 including amendments 2010 . BSI, London, UK.

BSI (2004) BS EN 1994-1-1: Eurocode 4: Design of composite steel and concrete structures, Part 1.1 General rules and rules for buildings. BSI, London, UK.

BSI (2005) BS EN 1993-1-1: Eurocode 3: Design of steel structures, Part 1.1 General rules and rules for buildings. BSI, London, UK.

Couchman G (2015) Minimum Degree of Shear Connection Rules for UK Construction to Eurocode 4. The Steel Construction Institute, Ascot, UK, Electronic Publication 405.

Johnson RP and Molenstra N (1991) Partial shear connection in composite beams for buildings. Proceedings of the Institution of Civil Engineers, Part 2 91(4): 679-704, http://dx.doi.org/10.1680/iicep.1991.17485.

Lam D, Elliott KS and Nethercot DA (2000) Designing composite steel beams with precast concrete hollow-core slabs. Proceedings of the Institution of Civil Engineers Structures and Buildings 140(2): 139-149, http://dx.doi. org/10.1680/stbu.2000.140.2.139.

Nethercot DA, Li TQ and Ahmed B (1998) Plasticity of composite beams at the serviceability limit state. The Structural Engineer 76(12): 289-293.

Newmark NM, Siess CP and Viesst IM (1951) Tests and analysis of composite beams with incomplete shear connection. Proceedings of the Society for Experimental Stress Analysis 9(1): 75-92.

Qureshi J, Lam D and Ye J (2011a) Effect of shear connector spacing and layout on the shear connector capacity in composite beams. Journal of Constructional Steel Research 67(4): 706-719.

Qureshi J, Lam D and Ye J (2011b) The influence of profiled sheeting thickness and shear connector's position on strength and ductility of headed shear connector. Engineering Structures 33(5): 1643-1656.

Ranzi G and Zona A (2007) A steel-concrete composite beam model with partial interaction including shear deformability of the steel component. Engineering Structures 29(11): 3026-3041.

Ranzi G, Bradford M and Uy B (2003) A general method of analysis of composite beams with partial interaction. Steel and Composite Structures 3(3): 169-184. 
SCI (The Steel Construction Institute) (2003) RT 1309: Resistance of Headed Stud Shear Connectors in CF 60 and CF 80 Decking Profiles (Confidential Report to Sponsor). The Steel Construction Institute, Ascot, UK. SCI (2010) NCCI: Modified Limitation on Partial Shear Connection in Beams for Buildings, PN002a-GB 2010. The Steel Construction Institute, Ascot, UK.
Weerasinghe MD and McConnel RE (1999) Load Testing of Two UBA Composite Beams. The Steel Construction Institute and University of Cambridge, Cambridge, UK.

Wright HD and Francis RW (1990) Tests on composite beams with low levels of shear connection. The Structural Engineer 68(15): 293-298.

\section{HOW CAN YOU CONTRIBUTE?}

To discuss this paper, please email up to 500 words to the editor at journals@ice.org.uk. Your contribution will be forwarded to the author(s) for a reply and, if considered appropriate by the editorial board, it will be published as discussion in a future issue of the journal.

Proceedings journals rely entirely on contributions from the civil engineering profession (and allied disciplines). Information about how to submit your paper online is available at www.icevirtuallibrary.com/page/authors, where you will also find detailed author guidelines. 